Pablo Fajdiga

Ljubljana, Eslovenia

\title{
LITTERAE SLOVENICAE EN MADRID
}

La promoción de la literatura eslovena en el mundo es una labor que exige mucho esfuerzo y dedicación, con el agravante de que sus resultados - positivos o negativos - no son palpables de manera inmediata. Por un lado está la dificultad de que el número de extranjeros que conocen el idioma esloveno es sumamente reducido y la traducción a las distintas lenguas debe ser realizada generalmente por traductores eslovenos. Por otro lado el mercado mundial está saturado por la producción literaria que se genera en países de mayor relevancia a nivel internacional que Eslovenia o en idiomas con mayor número de hablantes.

Una de las instituciones que con más ahínco se ha dedicado al imprescindible diálogo con distintas tradiciones culturales es sin duda la Asociación de escritors eslovenos que desde el año 1962 publica su revista literaria Litterae slovenicae que en sus comienzos apareció bajo el nombre de Le livre slovène. En sus páginas podemos encontrar - principalmente en inglés, francés y alemán- lo mejor de las letras eslovenas contemporáneas. En el año 1993 la prestigiosa institución enriqueció la lista de sus títulos con un cuadernillo de Cuentos eslovenos contemporáneos en español. Entre los autores de esta breve, pero representativa antología de prosa eslovena contemporánea se encontraban los cuentos de Drago Jančar, Lev Detela, Boštjan Seliškar, Andrej Blatnik, Lela B. Njatin, Igor Bratož, Milan Kleč, Jani Virk y Mart Lenardič. El prólogo fue redactado por el crítico y ensayista Tomo Virk, y la traducción estuvo a cargo de Lučka Poznič, Pavlinka Korošec Kocmur, Marjeta Drobnič y Pablo Fajdiga. Apenas dos años más tarde, en el año 1995, la Asociación de escritores eslovenos sorprendió al público lector hispanoparlante con un nuevo volumen, esta vez dedicado a la Poesía eslovena contemporánea - una sobria antología de la creación lírica de doce poetas, distintos entre sí tanto por las generaciones a las que pertenecen, cuanto por los estilos que cultivan y los temas que los ocupan. Los autores seleccionados fueron Dane Zajc, Kajetan Kovič, Svetlana Makarovič, Tomaž Šalamun, Milan Dekleva, Milan Jesih, Boris A. Novak, Jure Potokar, Brane Mozetič, Alojz Ihan, Aleš Debeljak y Uroš Zupan. El cuadernillo contiene también un ensayo introductorio, en el cual la crítica literaria Tea Štoka presenta un panorama global de la poesía eslovena contemporánea. La traducción estuvo a cargo de Jasmina Markič, Nina Kovič, Francisco Javier Uriz, Damjana Pintarič, Antonio Preciado, Barbara Pregelj, Marjeta Drobnič y Pablo Fajdiga.

En el momento de su publicación la Asociación eslovena de escritores creyó oportuno preparar en la capital española una velada literaria para presentar el nuevo volumen de Litterae slovenicae en español, en la que participaran algunos de lo más renombrados escritores y poetas de nuestro medio. La velada se llevó a cabo el 26 de octubre del año pasado en el Círculo de Bellas Artes de Madrid, donde en ese momento se estaba realizando la exposición plástica Ocho artistas eslovenos. (En la muestra presentaban sus obras Emerik Bernard, Mirko Bratuša, Sandi Červek, Gustav Gnamuš, Bojan Gorenec, Matjaž 
Počivavšek, Nataša Prosenc y Zdenka Žido.) La coordinación de la velada estuvo a cargo del escritor español Matías Escalera Cordero. En la oportunidad leyeron sus obras los poetas Tomaž Šalamun y Brane Mozetič y los escritores Drago Jančar y Andrej Blatnik.

Conviene destacar de manera especial que la primera parte de la velada literaria contó con la participación de un grupo de estudiantes del Departamento de Lenguas Romances de la Facultad de Filosofía y Letras de la Universidad de Ljubljana que bajo la dirección de la prof. Maja Turnher presentaron una selección de la poesía eslovena contemporánea titulada Las cinco estaciones del año. Polona Čuk, Veronika Mahnič, Tina Malič, Mojca Mavec, Nina Petrič, Mateja Rozman y Brigita Sklepič recitaron, fieles a una coreografia ingeniosa, moderna y sin fracturas, más de veinte textos poéticos, agrupados en cinco ciclos: primavera, verano, otoño, invierno, primavera. El espectáculo ideado por la prof. Maja Turnher dió lugar a un despliegue variado de motivos, temas, estilos y ritmos entre los que se debate la poesía eslovena contemporánea, logrando a la vez una conjugación armónica de las diferencias. El acompañamiento musical fue ideado y ejecutado por el músico esloveno Lado Jakša, que supo generar con sus instrumentos un espacio musical que se adecuaba plenamente a la palabra y al movimiento del espectáculo presentado.

La velada literaria preparada por la Asociación de escritores eslovenos junto con la participación del grupo de estudiantes del Departamento de Lenguas Romances de la Facultad de Filosofía de la Universidad de Ljubljana confirmó que la colaboración entre la Universidad y las distintas organizaciones e instituciones culturales no es meramente posible, sino que en ciertas áreas de intereses comunes puede llegar a dar excelentes resultados. Con este tipo de actividades extracurriculares los estudiantes universitarios pueden cumplir un papel de relevancia en los trabajos que se están llevando a cabo para dar a conocer al menos parte de aquel acervo cultural que hace a la identidad eslovena.

\section{Povzetek}

\section{LITTERAE SLOVENICAE V MADRIDU}

Promocija slovenske književnosti v svetu je težavna naloga. Društvo slovenskih pisateljev se temu posveča že od leta $1962 \mathrm{z}$ izdajanjem zbirke Litterae slovenicae. Leta $1995 \mathrm{je}$ v Madridu predstavilo krajšo antologijo slovenske sodobne poezije $v$ španščini. Na predstavitvi je sodelovala skupina študentov z Oddelka za romanske jezike in književnosti Filozofske fakultete Univerze v Ljubljani pod vodstvom prof. Maje Turnher. Uspeh tega literarnega večera dokazuje, da utegne biti sodelovanje med Univerzo in različnimi kulturnimi ustanovami posebej plodovito in učinkovito. 